\title{
EVALUATION OF THE PROTECTIVE EFFECT OF GALLIC ACID AGAINST ARSENIC-INDUCED GENOTOXICITY IN HEPG2 CELL LINE
}

\author{
NIDHYA TERESA JOSEPH, RAJASEKHAR MOKA* \\ Department of Cell and Molecular Biology, Manipal School of Life Sciences, Manipal Academy of Higher Education, Manipal, Karnataka, \\ India. Email: rsmoka@gmail.com
}

Received: 19 December 2019, Revised and Accepted: 13 January 2020

\section{ABSTRACT}

Objective: Arsenic has cytotoxic as well as mutagenic effect in human health due to its indirect effect on oxidative stress on the cells. We aimed to find out the effect of gallic acid (GA), a well-known natural antioxidant in ameliorating in heavy metal toxicity.

Methods: MTT assay was performed to determine the cytotoxicity of sodium arsenite $\left(\mathrm{NaAsO}_{2}\right)$ on HepG2 cells with the cytoprotectant GA at varying concentrations for exposure durations of $6 \mathrm{~h}, 12 \mathrm{~h}$, and $24 \mathrm{~h}$. Similarly, the alkaline version of the comet assay was performed to investigate the genotoxicity and assessment of oxidative stress of the cells using flow cytometry.

Results: Cells treated with $\mathrm{NaAsO}_{2}$ at various doses spanning a broad range of concentrations (5-500 $\left.\mu \mathrm{M}\right)$ showed a dose- and time-dependent decrease in cellular viability as observed. However, the effect of the proposed protectant, GA showed an increase in cellular viability in a concentrationdependent manner.

Conclusion: We assessed the cytotoxicity and genotoxicity induced by $\mathrm{NaAsO}_{2}$ to provide insight into the role of GA on arsenic-induced toxicity in liver cells and to shed light on its possible ameliorative effect at low concentrations in a time-dependent manner.

Keywords: Arsenic toxicity, Gallic acid, MTT assay, Comet assay, Flow cytometry.

(C) 2020 The Authors. Published by Innovare Academic Sciences Pvt Ltd. This is an open access article under the CC BY license (http://creativecommons. org/licenses/by/4. 0/) DOI: http://dx.doi.org/10.22159/ajpcr.2020.v13i3.36656

\section{INTRODUCTION}

Arsenic (As) is a semi-metallic compound that occurs naturally in the earth's crust. It is primarily found in environmental sources such as soil, rocks, water, and air and occurs in combination with other elements. Its inorganic forms, however, are highly toxic. Arsenic is one of the major chemical contaminants as stated by the World Health Organization (WHO) [1]. The primary source of arsenic toxicity is found to be water sources [2]. The occurrence of increased levels of arsenic is found in groundwater sources as compared to surface water sources such as rivers and lakes. This could occur due to contaminated groundwater caused by the accumulation of arsenic compounds on the bedrock, which further enters water sources through erosion [3]. High levels of arsenic in groundwater are found to be prevalent worldwide. Arsenic exposure through drinking water has been reported in many countries of the world [4]. The provisional guideline value for the high risk of arsenic in drinking water is $10 \mu \mathrm{g} / \mathrm{ml}$, as stated by the WHO. However, in India, its permissible levels are $0.05 \mathrm{mg} / \mathrm{L}$ [5]. Depending on the type of exposure to arsenic compounds, acute and chronic effects are typically observed. The acute exposure to arsenic in the form of larger doses is rare and can result in immediate clinical manifestations such as vomiting, diarrhea, abdominal pain, and muscle cramping [6]. Chronic effects ( $>50 \mu \mathrm{g} / \mathrm{ml}$ ) of arsenic, however, manifest in the form of liver diseases and can further contribute toward the development of bladder, skin, lungs, and liver cancer [7]. Associations between the exposure of arsenite during pregnancy and its effect on infant health and mortality have been correlated to studies related to impaired cognitive development [8].

Toxicity to arsenic compounds such as arsenate (As IV) impairs cellular interactions and energy production through molecular mimicry, whereas arsenite (As III) can exhibit cytotoxic effects by binding directly to sulfur bonds and cause the additional generation of reactive oxygen species (ROS) [9]. Genotoxic effects of arsenic include the formation of strand breaks in the deoxyribonucleic acid (DNA). Meta-arsenite is also shown to bind to the repeat regions of the telomere and causes erosion of the repeats and inhibition of cell proliferation [10]. Oxidative stress as mentioned is found to be one of the prime causes of arsenic-induced toxicity. This has led to the search for effective antioxidants that can counter the stress induced by highly reactive xenobiotic agents [11]. Pharmacologically active compounds or dietary sources are ideal for the protection or treatment against metal-induced toxicity [12]. One such compound is gallic acid (GA) which is a polyphenolic compound that exhibits high antioxidant properties compared to physiologically active and synthetic antioxidants [13]. GA is said to possess strong scavenging activity of reactive free radicals and leads to an increase in intracellular antioxidant capacity. In this study, arsenic-induced toxicity in a tissuespecific in vitro model of hepatocytes-HepG2 cells was studied due to the efficient methylation potential of arsenic compounds in the liver. The arsenic compound used in this study was sodium arsenite $\left(\mathrm{NaAsO}_{2}\right)$, to evaluate its cytotoxic and genotoxic potential and also explored the possible amelioration of arsenic toxicity with the help of GA, to test for any protective potential in terms of cytotoxicity, genotoxicity, and oxidative stress.

\section{METHODS}

\section{Chemicals}

$\mathrm{NaAsO}_{2}$ GR was purchased from Romali, American Preparate, India. Dulbecco's Modified Eagle's Medium (DMEM) and 0.1\% Trypsin were obtained from HiMedia, fetal bovine serum (FBS), 3-(4,5-dimethyl2-thiazolyl)-2,5-diphenyl-2H tetrazolium bromide (MTT), ethidium bromide (EtBr), Agarose, Triton X-100, and dichlorodihydrofluorescein diacetate (DCFH-DA) dye were purchased from Sigma-Aldrich, Bangalore, India. GA and dimethyl sulfoxide (DMSO) as purchased from SRL Chemicals, Pvt. Ltd., India, and Merck Life Sciences Pvt. Ltd., India, respectively. 
Cell culture and maintenance of HepG2 cell lines

HepG2 cell line was acquired from the National Centre for Cell Science, Pune, which was grown in DMEM with $10 \%$ FBS as a supplement. Cells maintained in T-25 and T-75 flasks were supplemented with the fresh medium until $70 \%$ confluency was obtained and they were subcultured every 2-3 days. Exponentially growing HepG2 cells were used for the following assays.

\section{Preparation of test solutions}

$\mathrm{NaAsO}_{2}$ was dissolved in autoclaved Milli-Q water to obtain a stock of $100 \mathrm{mM}$ and constituted with DMEM + 10\% FBS. GA was dissolved in the organic solvent, dimethyl sulfoxide, and DMSO (0.02\%), and a further stock solution of $100 \mathrm{mM}$ was made up with DMEM supplemented with $10 \%$ FBS. Further dilutions of $\mathrm{NaAsO}_{2} / \mathrm{GA}$ were prepared from the stock solution in culture medium for all the assays.

\section{Assessment of cytotoxicity induced by $\mathrm{NaAsO}_{2}$ by MTT assay}

MTT assay was performed to determine the cytotoxicity of $\mathrm{NaAsO}_{2}$ on HepG2 cell lines, the classic protocol used was modified to suit the present experiment [14]. HepG2 cells $\left(1 \times 10^{4}\right)$ were seeded into each well of a 96-well plate (Greiner, CellStar, India) and allowed to adhere for about $24 \mathrm{~h}$ in $5 \% \mathrm{CO}_{2}$ incubator. After the attachment of the cells to the plate, the media were then replaced with varying concentrations of $\mathrm{NaAsO}_{2}$ (As III) ranging from 5 to $500 \mu \mathrm{M}$ and were incubated for different durations, i.e. 12,24 , and 48 h. Following the incubation at different time points, arsenite-containing media were then replaced with $100 \mu \mathrm{L}$ MTT $(5 \mathrm{mg} / \mathrm{ml})$ and incubated for a minimum of $3 \mathrm{~h}$ at $37^{\circ} \mathrm{C}$. Crystals of formazan formed in purple color were solubilized by the addition of $100 \mu \mathrm{L}$ of DMSO. The optical density (OD) was then detected at $570 \mathrm{~nm}$ with a reference wavelength of $630 \mathrm{~nm}$, using a multiwell plate reader (Tecan, Austria) and measured using the software Magellan. Cell viability was calculated as follows:

$$
\% \text { Viability }=\left[\frac{\text { Test OD }}{\text { Control OD }}\right] \times 100
$$

\section{Effect of GA on cellular viability by arsenite-induced toxicity} assessed by MTT assay

Parallel to the previous method, $1 \times 10^{4}$ cells were seeded into each well of a 96-well plate and allowed to adhere for about $24 \mathrm{~h}$ in a humidified $5 \% \mathrm{CO}_{2}$ incubator. Cells were treated in batches as per the following scheme:

- Group A: Treatment of cells with GA alone in concentrations ranging from 0.5 to $30 \mu \mathrm{M}$ for $6 \mathrm{~h}, 12 \mathrm{~h}$, and $24 \mathrm{~h}$, respectively

- Group B: Pre-treatment of cells with GA in a range of concentrations $(0.5-30 \mu \mathrm{M})$ for $6 \mathrm{~h}, 12 \mathrm{~h}$, and $24 \mathrm{~h}$, respectively. Further treatment with a sublethal dose of arsenite $(25 \mu \mathrm{M})$ for $48 \mathrm{~h}$

- Group C: Pre-treatment of cells with GA in concentrations ranging from 0.5 to $30 \mu \mathrm{M}$ for $6 \mathrm{~h}, 12 \mathrm{~h}$, and $24 \mathrm{~h}$. Further treatment with $\mathrm{IC}_{50}$ dose of arsenite $(\sim 50 \mu \mathrm{M})$ for $48 \mathrm{~h}$

- Group D: Controls - positive controls - mitomycin, negative controls - DMSO, and individual doses arsenic ( $25 \mu \mathrm{M}$ and $50 \mu \mathrm{M})$ were added to the HepG2 cells.

Combinational MTT was performed using a pre-treatment of HepG2 cells with the proposed cytoprotectant, GA at varying concentrations ranging from 0.5 to $30 \mu \mathrm{M}$ for exposure durations of $6 \mathrm{~h}, 12 \mathrm{~h}$, and $24 \mathrm{~h}$. Following different pre-treatments, the medium was replaced with arsenite in sets of two concentrations:

1. A sublethal dose of arsenite $-25 \mu \mathrm{M}$ against GA concentrations ranging from 0.5 to $30 \mu \mathrm{M}$

2. IC $\mathrm{IC}_{50}$ dose of arsenite $-50 \mu \mathrm{M}$ against $\mathrm{GA}$ concentrations ranging from 0.5 to $30 \mu \mathrm{M}$.

The cells were treated with arsenite for $48 \mathrm{~h}$, following which the medium was replaced with MTT reagent $(5 \mathrm{mg} / \mathrm{ml})$ and incubated at $37^{\circ} \mathrm{C}$ for 3 h. The purple crystals of formazan were solubilized in $100 \mu \mathrm{L}$ of DMSO. The optical intensity was then detected at $570 \mathrm{~nm}$ with a reference wavelength of $630 \mathrm{~nm}$, using a spectrophotometer (Tecan, Austria) and measured using the software Magellan. The readings were analyzed, and the percentage viability was calculated as described earlier.

\section{Estimation of arsenite-induced genotoxicity by comet assay}

The alkaline version of the comet assay was performed to investigate the DNA damage/genotoxicity caused by the toxicant - $\mathrm{NaAsO}_{2}$, referred from the modified protocol $[15,16]$. Alkaline conditions enabled the detection of both single-strand and double-strand breaks in the genome. HepG2 cells exhibiting exponential growth were seeded into $6 \mathrm{~cm}$ culture dishes (Cell Star, Sigma, USA) and treated with a range of arsenite concentrations (10-50 $\mu \mathrm{M})$. A batch of cells was treated with $200 \mu \mathrm{M}$ of $\mathrm{H}_{2} \mathrm{O}_{2}$ as a control, for the standardization of the electrophoresis run time. A combination of the proposed protectant GA as pre-treatment for $6 \mathrm{~h}$ followed by arsenic treatment for a duration of $24 \mathrm{~h}$ was performed for comet analysis.

Following treatment, cells were harvested by trypsinization and the comet slides were prepared. Briefly, clean glass slides were coated with a thin layer of $1.5 \%$ normal melting agarose at $37^{\circ} \mathrm{C}$. Approximately $4 \times 10^{5}$ cells were harvested and centrifuged at $155 \times \mathrm{g}$ for $5 \mathrm{~min}$ followed by a phosphate-buffered saline wash. The pellet obtained was resuspended in $200 \mu \mathrm{l}$ of $0.75 \%$ low melting agarose which was mixed well to form the second layer and placed on ice. About $150 \mu \mathrm{l}$ of $0.75 \%$ low melting agarose without cells was used to form the third layer correspondingly. After solidification, agarose-embedded glass slides were immersed in a lytic working solution $(2.5 \mathrm{M} \mathrm{NaCl}, 100 \mathrm{mM}$ Tris base, $0.2 \mathrm{M} \mathrm{NaOH}$, and $100 \mathrm{mM}$ ethylenediaminetetraacetic acid [EDTA], DMSO, and trypsin), overnight at $4^{\circ} \mathrm{C}$.

The slides were then transferred carefully to an alkaline electrophoresis buffer (10 N NaOH and $200 \mathrm{mM}$ EDTA-pH 13) for $30 \mathrm{~min}$ and gel electrophoresis was performed at $19 \mathrm{~V}, 300 \mathrm{~mA}$, further for a range of time points between 18 and $30 \mathrm{~min}$. A neutralization buffer $(0.4 \mathrm{M}$ Tris at pH 7.9) was then used to neutralize the slides and was briefly dehydrated with 70-90\% alcohol. The glass slides were stained under a reduced light with $\mathrm{EtBr}(2 \mathrm{mg} / \mathrm{ml})$.

The samples were further visualized at $\times 40$ using a fluorescence microscope (Olympus Microscopes, Japan) at $525 \mathrm{~nm}$ excitation filter and the images were captured using a CCD camera using the software CellSens (CellSens B.V., Netherlands). Comet features such as \% DNA and olive moment were scored for each sample and analyzed using the Open Comet tool using ImageJ software (Wisconsin, USA).

\section{Assessment of oxidative stress of the cell (ROS production) by flow cytometry}

ROS generated by the cell in response to arsenic and the oxidative effect of GA on arsenic-induced toxicity was estimated by the ROS assay protocol outlined by Satish Rao et al. [17] with minor modifications. Exponentially growing cells were seeded at a density of $4-5 \times 10^{5}$ cells per well in a 6-well plate (Cell Star, Sigma, USA). Following $24 \mathrm{~h}$ of culture initiation, the cells were treated in batches in the following manner:

1. As treatment: Cells were treated with increasing doses of $\mathrm{NaAsO}_{2}$ in a range of concentrations $(10-50 \mu \mathrm{M})$ for $24 \mathrm{~h}$

2. Combination of GA + As: Two concentrations of GA were used, $5 \mu \mathrm{M}$ and $20 \mu \mathrm{M}$ as a pre-treatment for $6 \mathrm{~h}$ and $12 \mathrm{~h}$ against a sublethal dose of arsenite, $25 \mu \mathrm{M}$, for $24 \mathrm{~h}$.

After the respective treatment of the cells, the media were discarded, and the cells were washed with $1 \mathrm{ml}$ of PBS to remove any residual serum which could interfere with the binding of the dye DCFH-DA to the cells. A working solution of $5 \mu \mathrm{M}$ of DCFH-DA dye was prepared from a stock of $10 \mathrm{mM}$, dissolved in DMEM (serum-free). Roughly $3 \mathrm{ml}$ of the working dye solution was dispensed into the wells and incubated for $30 \mathrm{~min}$ in a humidified $\mathrm{CO}_{2}$ incubator. Following incubation, the dye solution was discarded, and cells were washed briefly with $1 \mathrm{ml}$ of PBS. The cells were harvested by mild trypsin treatment of 300 $\mu \mathrm{l}$ and centrifuged at $1200 \mathrm{rpm}(155 \times \mathrm{g})$ for $1 \mathrm{~min}$. The pellet was washed with PBS and the final pellet obtained was further resuspended 
in $1 \mathrm{ml}$ of PBS. The fluorescence of the cells was read at $480 \mathrm{~nm}$ by a flow cytometer (CyFlow Space, Sysmex Partec, Germany) and the software FloMax was used for analysis. Mean fluorescence intensity and geometric mean were used to calculate total fluorescence intensity. The results were expressed in terms of fluorescence intensity.

\section{Statistical analysis}

Spectrophotometric readings were taken in quadruples and the experiments were independently repeated in triplicates. Statistical analytic tools include Student's t-test and significance between the groups was estimated using one- and two-way analysis of variance with the help of the software, GraphPad Prism 8 (GraphPad Software Inc., San Diego, CA). All data were expressed in the form of mean \pm SD. $\mathrm{p}<0.05$ was considered statistically significant.

\section{RESULTS}

Assessment of cytotoxicity induced by $\mathrm{NaAsO}_{2}$ by MTT assay Cells treated with $\mathrm{NaAsO}_{2}$ at various doses spanning a broad range of concentrations $(5-500 \mu \mathrm{M})$ showed a dose-dependent and timedependent decrease in cellular viability, as shown in Fig. 1 . The $\mathrm{IC}_{50}$ value of arsenite was estimated to be between 40 and $60 \mu \mathrm{M}$ for an exposure duration of 24-48 h. Log scale of arsenite concentration was taken for this estimation. The $\mathrm{IC}_{50}$ for the three time points $(12,24$, and $48 \mathrm{~h}$ ) was estimated to be $506 \mu \mathrm{M}, 143 \mu \mathrm{M}$, and $47.63 \mu \mathrm{M}$, respectively.

Effect of GA on cellular viability by arsenite-induced toxicity assessed by MTT assay

The effect of the proposed protectant, GA was also evaluated by the MTT assay in a dose-dependent $(5-30 \mu \mathrm{M})$ and time-dependent increase in cellular viability (6-24 h), wherein increasing concentrations of GA on the cells showed a steady increase in cellular viability $(\sim 100 \%)$ with no significant differences observed between the control and the treatments. It was observed from the graph that $12 \mathrm{~h}$ showed maximum cellular viability and GA was observed to show negligible cytotoxic effects on the cell line by its own (Fig. 2).

Combinatorial treatment of $\mathrm{GA}$ and $\mathrm{NaAsO}_{2}$ with a pre-treatment of $0.5-30 \mu \mathrm{M}$ followed by a sublethal dose of arsenite $(25 \mu \mathrm{M})$ showed a significant increase in cellular viability compared to the cells treated with arsenite alone (Fig. 3a) ( $<<0.01)$. The optimum concentration of $\mathrm{GA}$ was found to be at $5 \mu \mathrm{M}$ treated with a sublethal dose of arsenite $(25 \mu \mathrm{M})$, following which there was a resultant decrease in cellular viability (Fig. 3a). However, the effect of GA on a higher dose of arsenic did not show any significant difference in cell viability (Fig. 3b).

Estimation of arsenite-induced genotoxicity by comet assay Comet assay enabled the assessment of the genotoxicity induced by $\mathrm{NaAsO}_{2}$ in varying doses for different time points against a positive control, $\mathrm{H}_{2} \mathrm{O}_{2}$. The electrophoresis run time and time of exposure of arsenite were standardized to be $20 \mathrm{~min}$ and $24 \mathrm{~h}$, respectively. The $\%$ head and tail DNA induced by $\mathrm{NaAsO}_{2}$ were also quantified (Fig. 4). Combination treatment of GA and arsenite was assessed by comet assay, wherein $5 \mu \mathrm{M}$ of GA showed a significant reduction in head and tail DNA \% and olive moment (Fig. 5) ( $<<0.001)$.

Assessment of the oxidative stress of the cell (ROS production) by flow cytometry

The oxidative state of the cell was evaluated in terms of ROS production by the binding of the fluorescent probe DCFH-DA and its oxidation by ROS to a reduced state that could be quantified with the help of fluorescence detection by fluorescence-activated cell sorting, which can measure the ROS production of cells individually. The treatment of cells with increasing doses of arsenic induced an increase in the ROS production, measured in terms of mean fluorescence intensity (Fig. 6) ( $p<0.0001)$. Combinatorial treatment, on the other hand, resulted in a decrease in mean fluorescence intensity in comparison to the treatment with the toxicant by itself (Fig. 7).

\section{DISCUSSION}

Arsenic toxicity is one of the major heavy metal toxicities commonly observed due to several environmental and anthropogenic activities. It enters biological systems through the oral route, mainly through the ingestion of arsenic-laden water and in rare cases through surface contact with the skin. Its exposure can cause some adverse effects on human health and is a major contributor to the carcinogenesis of vital organs such as the liver, lungs, bladder, and skin [18]. Its metabolism in biological systems through the one-carbon and transsulfuration pathway leads to oxidative stress in cells, imparting its indirect effect on the cellular and DNA levels [19]. The use of antioxidants such as GA that is naturally derived can be administered through dietary supplements to combat such heavy metal toxicity or serve as a protectant [20].

This study assesses the cytotoxic and genotoxic potential of arsenic on HepG2 cell lines taken as an in vitro model. Cytotoxicity induced by $\mathrm{NaAsO}_{2}$ was assessed with the help of a classic cell viability assay that employed the use of MTT reagent. The $\mathrm{IC}_{50}$ of arsenite was estimated to be around 40-60 $\mu \mathrm{M}$ for an exposure duration of 24-48 h which was found to be in concordance with a previous study [21]. The equivalent dose in humans for the range of doses taken is around 5-10 $\mu \mathrm{g} / \mathrm{L}$. This indicates that chronic dosing of arsenite on cell lines led to an increase in cell death. As stated by Watanabe et al. [22], high concentrations of arsenite could lead to the inactivation of methyltransferases that are required in arsenic metabolism and further downstream detoxification processes. Cells treated with increasing doses of GA alone for 6-24 h showed an increase in cellular viability (Fig. 2), which was found to be non-toxic at all concentrations used. On the contrary, in the combinatorial MTT experiment, it was observed that cells which were

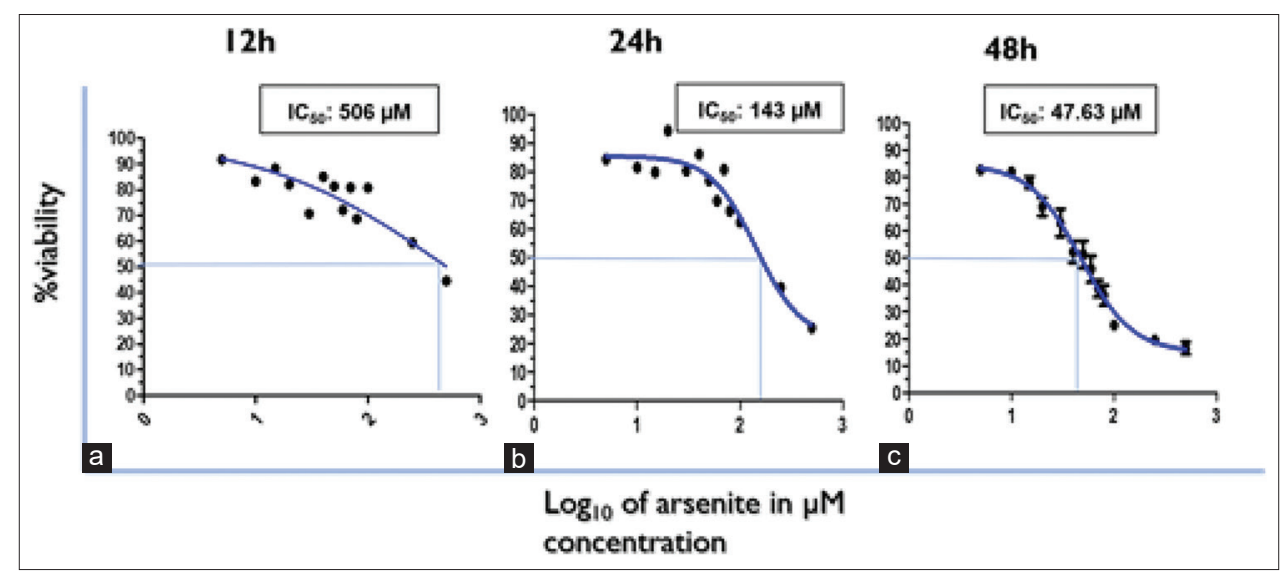

Fig. 1: Representative line graphs showing a change in cellular viability in a concentration and time-dependent decrease at (a) $12 \mathrm{~h}$, (b) $24 \mathrm{~h}$, and (c) $48 \mathrm{~h}$ for 5-500 $\mu \mathrm{M}$ of $\mathrm{NaAsO}_{2}(\mathrm{n}=3)$ where the log of concentration is taken as the X-axis against percentage of cellular viability. The $\mathrm{IC}_{50}$ for the three time points was estimated at $506 \mu \mathrm{M}, 143 \mu \mathrm{M}$, and $47.63 \mu \mathrm{M}$, respectively 


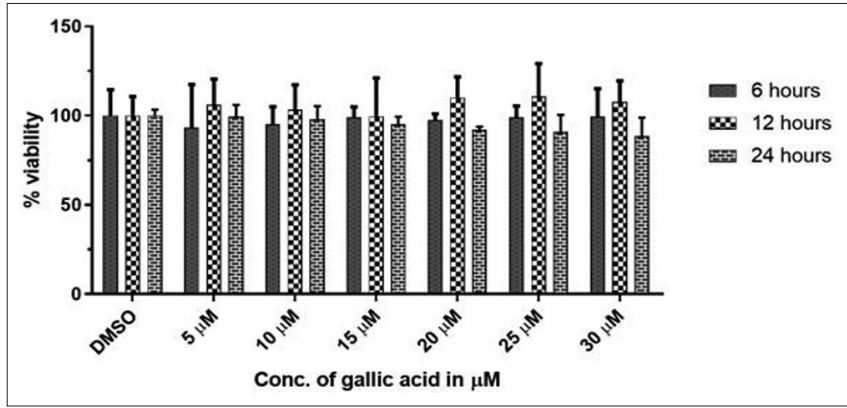

Fig. 2: Bar graphs showing the changes in percentage of cells on the treatment with gallic acid (GA) (5-30 $\mu \mathrm{M})$ for $6 \mathrm{~h}, 12 \mathrm{~h}$, and $24 \mathrm{~h}$. GA was found to be non-toxic at all concentrations and in increasing the duration of exposure

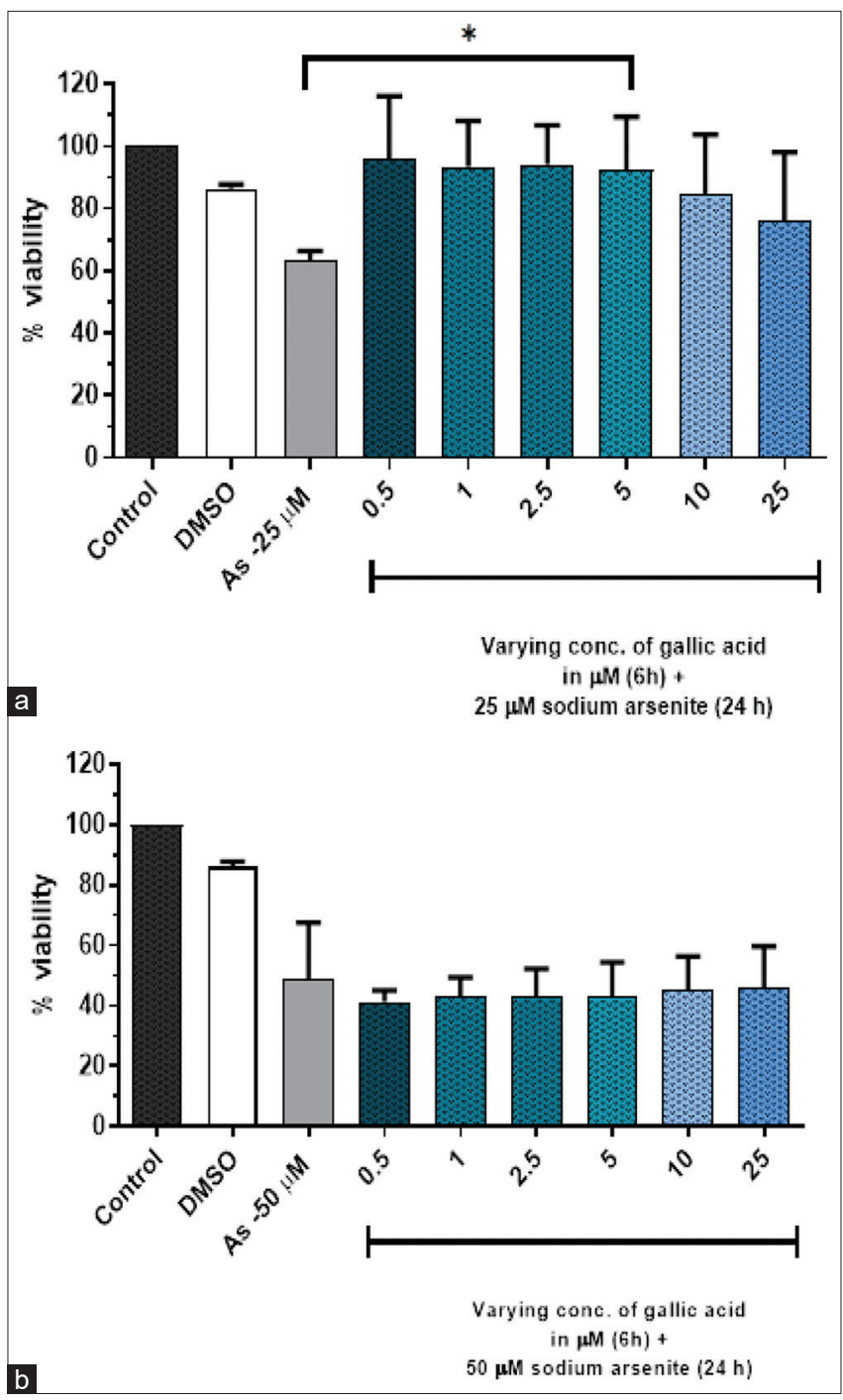

Fig. 3: The effect of a pre-treatment of gallic acid in concentrations ranging from 0.5 to $25 \mu \mathrm{M}$ for $6 \mathrm{~h}$ followed by (a) $25 \mu \mathrm{M}$ and (b) $50 \mu \mathrm{M} \mathrm{NaAsO} \mathrm{O}_{2}$ for $24 \mathrm{~h}$. A significant observation was found until about $5 \mu \mathrm{M}$ in the $24 \mu \mathrm{M}$ treatment $\left({ }^{*} \mathrm{p}<0.01\right)$

preconditioned with GA followed by treatment with arsenite depicted a significant increase in cellular viability, in comparison to the cells treated with arsenite alone (Fig. 3). Higher doses of arsenite along with increasing concentrations of GA, on the other hand, did not show any significant decrease in cell viability.

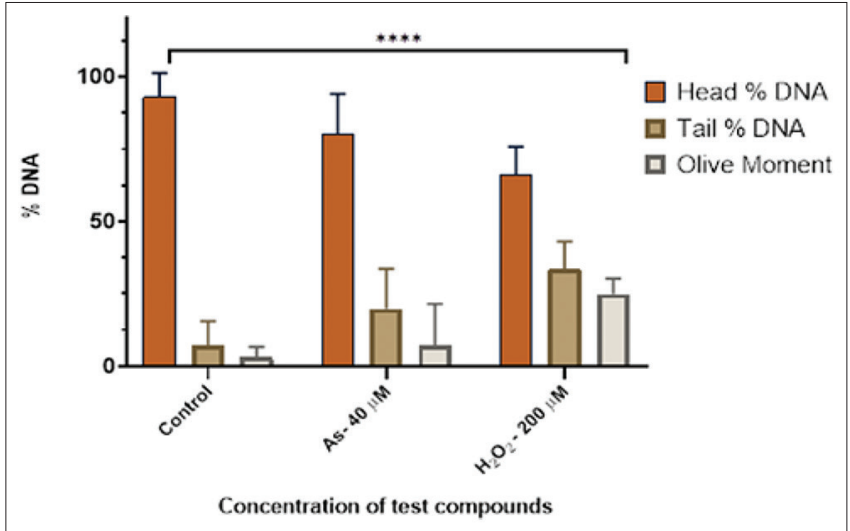

Fig. 4: Bar graphs showing a change in \% head and tail DNA and the olive moment when treated with arsenite at $40 \mu \mathrm{M}$, compared against a positive control $-\mathrm{H}_{2} \mathrm{O}_{2}(200 \mu \mathrm{M})$ treated for $24 \mathrm{~h}$. Significant differences were observed between treated and control groups in terms of variations in \% head and tail DNA and subsequent reduction in an olive tail moment $(p<0.0001)$

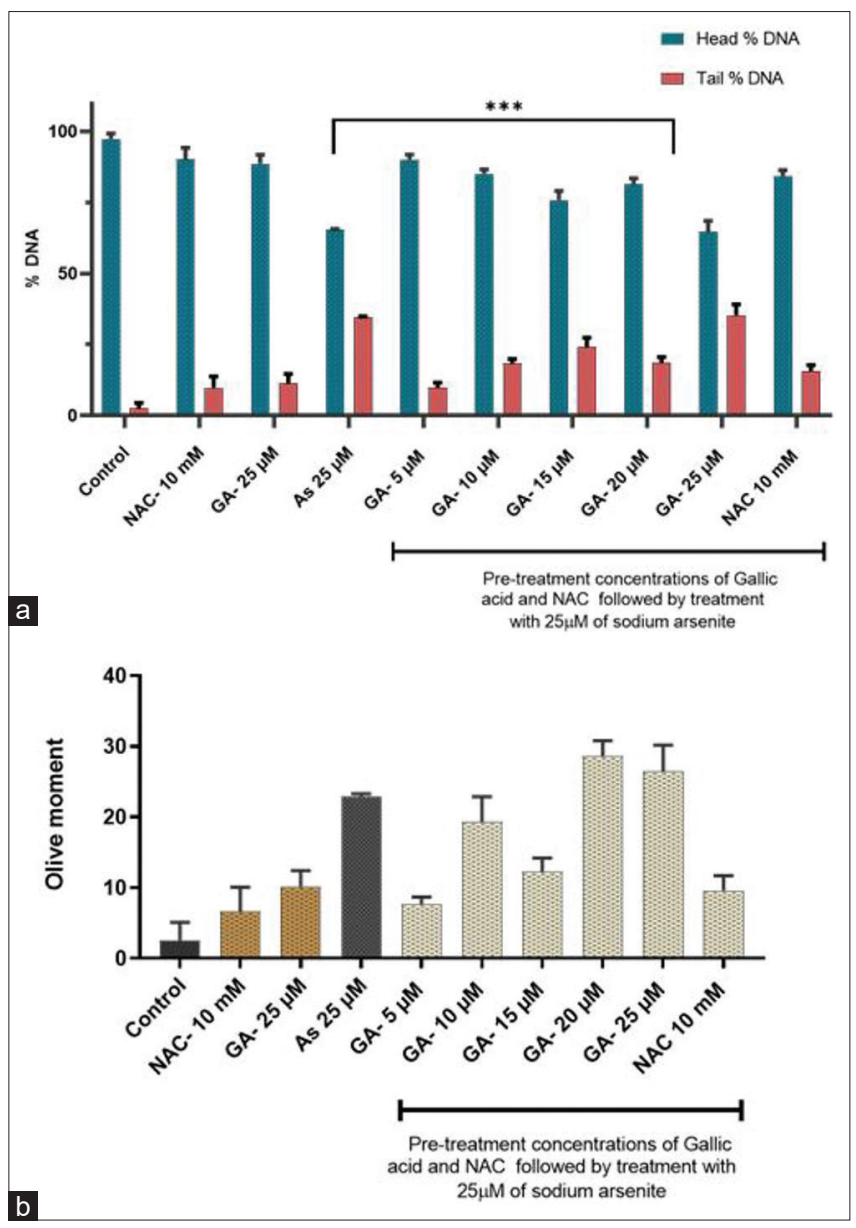

Fig. 5: Comet analysis of different treatment groups along with the combination of gallic acid (5-25 $\mu \mathrm{M})+25 \mu \mathrm{M}$ of $\mathrm{NaAsO}_{2}$, showing variations in (a) \% head DNA, \% tail DNA; (b) olive moment as a measure of genotoxicity. The relative decrease in comet head and a relative decrease in comet tail \% DNA was found to be statistically significant at $5 \mu \mathrm{M} \mathrm{GA}+25 \mu \mathrm{M}(* * * \mathrm{p}<0.0001)$

Similarly, as shown in other toxicity studies, it is observed that an increase in concentrations of the pure form of GA could lead to further cell death, due to its pro-oxidant activity after a threshold concentration $[23,24]$. 


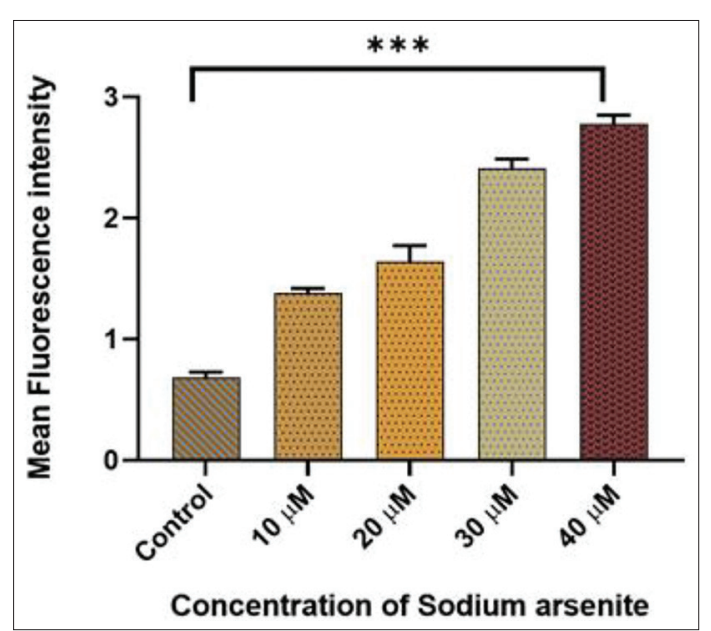

Fig. 6: Analysis of mean fluorescence intensity of cells in increasing doses of arsenite (10-40 $\mu \mathrm{M})$ expressed as arbitrary units that are indicative of an increase in ROS production in a dose-dependent manner. Statistical significance was observed $(* * * \mathrm{p}<0.0001)$

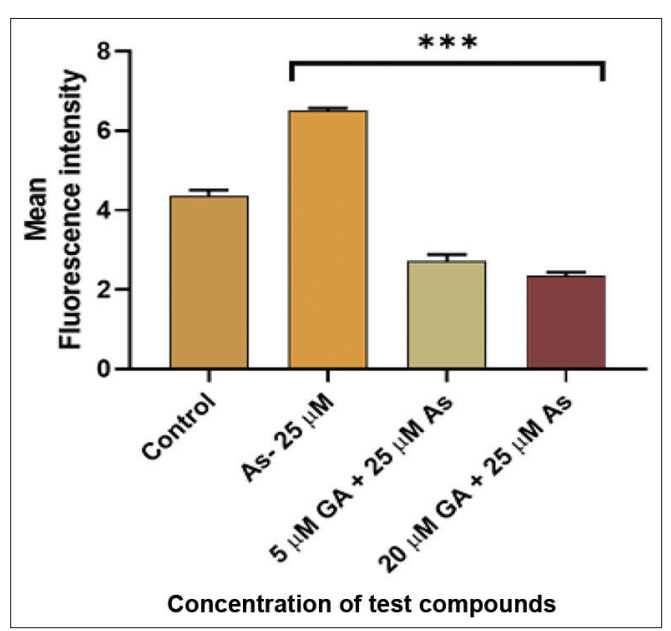

Fig. 7: Evaluation of variation in ROS production as a result of the pre-treatment of cells with gallic acid ( $5 \mu \mathrm{M}$ and $20 \mu \mathrm{M})$ against that of arsenite $(25 \mu \mathrm{M})$ treated alone. Significant reduction of ROS levels as a measure of mean fluorescent intensity was observed $(* * * p<0.0001)$

This could be attributed due to an increase in xenobiotic load on the cell lines as a result of the combinatorial treatment of arsenite and GA or this could indicate a possible interaction between them. From the combination assay, it was observed that the time of exposure of the pre-treatment of GA was found to be critical for the effective increase in cellular viability, indicating the possible cytoprotective nature of GA against arsenite-induced toxicity but only observed at a lower concentration, in which it exhibits non-cytotoxic activity.

Further experimentation was performed to assess the genotoxicity induced by arsenite, with the help of the alkaline comet assay. The genotoxic effect of arsenite was confirmed by the decrease in \% head DNA of the comet with a resultant increase in tail \% DNA and olive moment, thereby indicating DNA damage in the form of strand breaks, single- or double-stranded DNA breaks. Combinatorial treatment of arsenite and GA performed subsequently, showed a significant decrease in tail \% DNA and olive tail moment with a resultant increase in head $\%$ DNA (Fig. 5). The extent of damage caused to the genome may be observed in the ability of arsenic to alter essential pathways such as Nrf/HO1 signaling pathway and other cancer-related pathways. These genotoxic effects may result in the development of carcinogenesis and result in adverse health effects. Polyphenols such as GA serve to revert the condition of the cell by playing with these pathways and stabilizing them [25].

The cellular oxidative state of the cell was further assessed by ROS levels quantified using flow cytometry. The binding of the dye DCFHDA to ROS and its subsequent reduction to a fluorophore enabled the detection of ROS as a measure of relative fluorescence intensity/fold change. As observed, there was a steady increase in the production of ROS with an increase in the concentration of arsenite (in a range of $10-40 \mu \mathrm{M})$. On the contrary, cells treated with GA at a tolerable concentration of $5 \mu \mathrm{M}$ showed a significant decrease in ROS production except beyond higher concentrations of $20 \mu \mathrm{M}$, which again confirmed the threshold at which GA exhibits its oxygen scavenging capability.

The study of antioxidants such as GA to mitigate arsenic-induced toxicity has also been recently reported in the previous toxicology studies. A study conducted by Gholamine et al. [26] showed that GA was found to target organs such as the liver and kidney specifically that can aid in its amelioration and alteration in biochemical parameters which reduce its toxic effects. Thus, the antioxidative potential of GA proves to be substantial against arsenic toxicity. Other studies such as combination therapy, by the utilization of chelating agents and antioxidants, have proven to be effective in toxicity studies [27]. Thus, the combination therapy may serve as a suggested therapeutic for arsenic toxicity, in replacement for the commonly used and less efficient treatment options.

\section{CONCLUSION}

We assessed the cytotoxicity and genotoxicity induced by $\mathrm{NaAsO}_{2}$ to provide insight into the role of GA on arsenic-induced toxicity in liver cells and to shed light on its possible ameliorative effect at low concentrations in a time-dependent manner. The antigenotoxic potential was also observed significantly with the use of GA. This naturally occurring compound may prove to be of therapeutic value for the treatment of various liver diseases. However, due to its low threshold for non-cytotoxic effects, further research using specific models that investigate the mechanism and biochemistry of these compounds is required to be done, to explore the definite role of GA in arsenic-induced toxicity.

\section{ACKNOWLEDGMENT}

We are grateful to Director, MSLS, Manipal Academy of Higher Education, Manipal, for facilities provided. We acknowledge our technical staff for their assistance. Its great pleasure to thank Prof. Satish Rao BS for his kind support.

\section{AUTHORS' CONTRIBUTIONS}

Nidhya Teresa Joseph contributed to conducting experiments, collection of data, and preparation of manuscript. Moka Rajasekhar, conceptualization of the article, guidance, and feedback.

\section{CONFLICTS OF INTEREST}

We declare that we have no conflicts of interest.

\section{FUNDING}

The author(s) received no specific funding for this work.

\section{REFERENCESS}

1. Mandal BK, Suzuki KT. Arsenic round the world: A review. Talanta 2002;58:201-35

2. Hopenhayn-Rich C, Biggs ML, Smith AH, Kalman DA, Moore LE. Methylation study of a population environmentally exposed to arsenic in drinking water. Environ Health Perspect 1996;104:620-8.

3. Ravenscroft P, Brammer H, Richards K. Arsenic Pollution A Global 
Synthesis. Chichester: John Wiley and Sons; 2011.

4. Chandra S, Saini AK, Gupta AK. Arsenic: A harmful and desecrate compound for the humans. Asian J Pharm Clin Res 2019;12:24-9.

5. Kumar M, Puri A. A review of permissible limits of drinking water. Indian J Occup Environ Med 2012;16:40-4

6. Ratnaike RN. Acute and chronic arsenic toxicity. Postgrad Med J 2003;79:391-6.

7. Hong YS, Song KH, Chung JY. Health effects of chronic arsenic exposure. J Prev Med Public Health 2014;47:245-52.

8. Saha JC, Dikshit AK, Bandyopadhyay M, Saha KC. A review of arsenic poisoning and its effects on human health. Crit Rev Environ Sci Technol 1999;29:281-313.

9. Khairul I, Wang QQ, Jiang YH, Wang C, Naranmandura H. Metabolism, toxicity and anticancer activities of arsenic compounds. Oncotarget 2017;8:23905-26

10. Jeon BG, Kumar BM, Kang EJ, Maeng GH, Lee YM, Hah YS, et al. Differential cytotoxic effects of sodium meta-arsenite on human cancer cells, dental papilla stem cells and somatic cells correlate with telomeric properties and gene expression. Anticancer Res 2011;31:4315-28.

11. Kurutas EB. The importance of antioxidants which play the role in cellular response against oxidative/nitrosative stress: Current state. Nutr J 2016;15:71.

12. Ercal N, Gurer-Orhan H, Aykin-Burns N. Toxic metals and oxidative stress part I: Mechanisms involved in metal-induced oxidative damage. Curr Top Med Chem 2001;1:529-39.

13. Hosseinzadeh A, Houshmand G, Goudarzi M, Sezavar SH, Mehrzadi S, Mansouri E, et al. Ameliorative effect of gallic acid on sodium arsenite-induced spleno-, cardio-and hemato-toxicity in rats. Life Sci 2019;217:91-100.

14. Alley MC, Scudiero DA, Monks A, Hursey ML, Czerwinski MJ, Fine DL, et al. Feasibility of drug screening with panels of human tumor cell lines using a microculture tetrazolium assay. Cancer Res 1988;48:589-601.

15. Singh NP, McCoy MT, Tice RR, Schneider EL. A simple technique for quantitation of low levels of DNA damage in individual cells. Exp Cell Res 1988;175:184-91.

16. Nandhakumar S, Parasuraman S, Shanmugam MM, Rao KR, Chand P, Bhat BV. Evaluation of DNA damage using single-cell gel electrophoresis (Comet Assay). J Pharmacol Pharmacother 2011;2:107-11.

17. Satish Rao BS, Sreedevi MV, Nageshwar Rao B. Cytoprotective and antigenotoxic potential of mangiferin, a glucosylxanthone against cadmium chloride induced toxicity in HepG2 cells. Food Chem Toxicol 2009;47:592-600.

18. Liu SX, Davidson MM, Tang X, Walker WF, Athar M, Ivanov V, et al. Mitochondrial damage mediates genotoxicity of arsenic in mammalian cells. Cancer Res 2005;65:3236-42.

19. Kim HS, Kim YJ, Seo YR. An overview of carcinogenic heavy metal: Molecular toxicity mechanism and prevention. J Cancer Prev 2015;20:232-40

20. Carocho M, Ferreira IC. A review on antioxidants, prooxidants and related controversy: Natural and synthetic compounds, screening and analysis methodologies and future perspectives. Food Chem Toxicol 2013;51:15-25.

21. Abiko Y, Shinkai Y, Sumi D, Kumagai Y. Reduction of arsenic-induced cytotoxicity through Nrf2/HO-1 signaling in HepG2 cells. J Toxicol Sci 2010;35:419-23.

22. Watanabe T, Ohta Y, Mizumura A, Kobayashi Y, Hirano S. Analysis of arsenic metabolites in HepG2 and AS3MT-transfected cells. Arch Toxicol 2011;85:577-88.

23. Kobayashi H, Oikawa S, Hirakawa K, Kawanishi S. Metal-mediated oxidative damage to cellular and isolated DNA by gallic acid, a metabolite of antioxidant propyl gallate. Mutat Res 2004;558:111-20.

24. Kong KW, Mat-Junit S, Aminudin N, Hassan FA, Ismail A, Abdul Aziz A. Protective effects of the extracts of Barringtonia racemosa shoots against oxidative damage in HepG2 cells. PeerJ 2016;4:e1628.

25. Pandey KB, Rizvi SI. Plant polyphenols as dietary antioxidants in human health and disease. Oxid Med Cell Longev 2009;2:270-8.

26. Gholamine B, Houshmand G, Hosseinzadeh A, Kalantar M, Mehrzadi S, Goudarzi M. Gallic acid ameliorates sodium arsenite-induced renal and hepatic toxicity in rats. Drug Chem Toxicol 2019;25:1-2.

27. Ambasta SK, Kumari S, Sinha UK. Anticlastogenicity of Tinospora cordifolia stem extract against arsenic genotoxicity in Mus musculus bone marrow erythrocytes using micronucleus assay. Int $\mathrm{J}$ Pharm Pharm Sci 2017;9:260-4. 